\title{
Characterizing the global context for cross-cultural healthcare work by regions of the world
}

\author{
Mark Strand ${ }^{\mathrm{a}}$, Eckert Paulson ${ }^{\mathrm{b}}$ and Timothy Myrick ${ }^{\mathrm{c}}$ \\ a PhD, Professor, School of Pharmacy and Department of Public Health, North Dakota State University, Fargo, ND \\ ${ }^{b}$ Country Director for NGO in Central Asia \\ ${ }^{\mathrm{c}} \mathrm{MD}$, Assistant Professor, University of Missouri at Kansas City Family Medicine, Kansas City, MO
}

\begin{abstract}
Healthcare missionaries ( $n=393$ ) from 18 English-speaking countries, serving in 67 countries, were surveyed. With an average of 11 years of field experience and working primarily in the local language, participants in this study were able to report on healthcare situations and experience for expatriate healthcare missionaries in their countries of service. The healthcare institutions in most countries of the world were reported to be improving. Most countries were reported hospitable to the presence of expatriate missionaries, but there also existed some resistance to expression of Christian faith in the workplace. As mission organizations consider where to place healthcare professionals for medical service, consideration should be given to the trends and opportunities present in different regions of the world, so as to achieve the greatest outcomes and to provide the best match between the missionary and the context in which they work.
\end{abstract}

\section{Introduction}

There are an estimated 400,000 Christian missionaries working cross-culturally around the world. 127,000 of them are from the United States. ${ }^{1}$ 42,000 North American missionaries are serving in assignments of four or more years. ${ }^{2}$ Healthcare professionals make up a significant portion of the missionary workforce, and among some organizations, it is growing. ${ }^{3,4}$ At the CMDA Medical Missions Summit in Atlanta in 2012 , it was determined that $6.4 \%$ of the missionaries in the eight organizations attending were involved in healthcare. ${ }^{5}$ Of the 66 evangelical missions organizations studied in the Global Healthcare Workers Needs Assessment, 24\% of new missionary candidates in 2013 were healthcare workers. ${ }^{6}$ In this paper, healthcare missionaries are considered those whose service in the healthcare field is done directly or indirectly in support of the spiritual purposes of their sending organization. The purpose of this paper is to describe the geographic context in which these missionaries serve, the unique characteristics of each region of the world, and how these characteristics impact the work of these missionaries.

Since the 1960s, different regions and countries of the world have adopted different stances to healthcare mission work. After independence, some African nations called for a moratorium on Christian missions work in general. Yet most African nations have maintained an open door policy toward Christian missionaries, except for the Muslim nations in North Africa. Most Asian nations have adopted a position of national sovereignty such that religious worker visas have not been particularly welcomed. Most

Nov 2015. Christian Journal for Global Health 2(2): 23-38. 
South American countries have a Roman Catholic history and, thus, have remained open to Christian missionaries. In recent decades, many countries around the world have developed their economy and their own national healthcare systems, becoming less dependent on Christian health ministries.

Healthcare missionaries are particularly vulnerable to mental health challenges given the nature of their work. ${ }^{7,8}$ Unlike physicians in private practice or government service, missionary doctors are the "poorest and most isolated of [their] profession." ${ }^{9}$ Traumatic experiences such as natural disasters, warfare, terrorism, and epidemics are experienced frequently by healthcare missionaries, not to mention the added anxiety of feeling responsible for spouses and children likewise subjected to the same risks. There are many areas in the world where security issues are a daily concern and real dangers are a daily part of healthcare professionals' lives. Healthcare missionaries also experience significant levels of anxiety associated with occupational issues, acculturation, and physical illness. ${ }^{10,11}$ Added administrative and leadership responsibilities are also contributing factors. In recent years, however, many authors have pointed to a need for increased research in the field to better support healthcare mission-aries. ${ }^{12}$

The present study set out to determine the distribution of surveyed medical missionaries by region of the world and the characteristics of those regions. Experiences of medical missionaries in those regions differ in various ways. An important factor is the attitude of their host government toward their presence in the country. Finally, trends in healthcare in the major regions of the world are explored.

\section{Materials and Methods \\ Instrument}

The Patterns and Responses in Intercultural Service in Medicine (PRISM) Survey was designed and administered by an expert team of researchers associated with the Christian Medical and Dental Association (CMDA) in 2010-2011.
The purpose of the cross-sectional survey was to determine the current challenges and opportunities in medical missions from the perspective of English-speaking medical missionaries from Western countries.

The PRISM Survey contained 34 items, as described below. Statements were measured using Likert scales, while questions gathered data in the form of categorical and continuous variables. Among the variables assessed were depression and anxiety. Depression and anxiety scores were derived from two separate questions as follows: On a scale of 0 to 5 ( $0=$ none to $5=$ significant $)$, how serious a period of [anxiety, depression] have you ever experienced? The Diagnostic and Statistical Manual of Mental Disorders (DSM) IV diagnostic criteria and the Patient Health Questionnaire (PHQ-9) for depression and anxiety were not used because the length and nature of the survey did not allow for inclusion of the number of questions needed to make a diagnosis. $^{13,14}$

Role satisfaction was measured using three items: (1) With regard to your current role as a cross-cultural medical worker, are you: $(1=\mathrm{ex}$ tremely satisfied to $5=$ not satisfied); (2) I am satisfied with the balance of medical and nonmedical aspects of my work: $(1=$ strongly agree to $5=$ strongly disagree); and (3) The role I currently fill is consistent with what I envisioned before coming to the field: $(1=$ strongly agree to $5=$ strongly disagree). Respondents were asked about the attitude of the local health bureau toward their presence as a foreigner $(1=$ unfavorable to $5=$ highly favorable) and the relative ease of obtaining permission to initiate effective longterm medical work for expatriate medical workers in that country $(1=$ getting harder, $2=$ about the same, $3=$ easier, $4=$ don't know). Additional variables included gender, age, professional discipline, current country of service, language used at work, years of service in cross-cultural medical work, and years of intended service.

Respondents were asked to report their region of service from the following options: South America (Bolivia, Chile, Dominican Re- 
public, Ecuador, Guatemala, Haiti, Honduras, Paraguay, and Peru), Africa (Angola, Benin, Cameroon, Central African Republic, Chad, Democratic Republic of Congo, Ethiopia, Gabon, Ghana, Ivory Coast, Kenya, Lesotho, Liberia, Madagascar, Malawi, Mauritania, Mozambique, Namibia, Niger, Nigeria, Rwanda, Senegal, South Africa, Sudan, Tanzania, Uganda, Zambia, and Zimbabwe), Middle East (Afghanistan, Albania, Bahrain, Bangladesh, Jordan, Kazakhstan, Pakistan, United Arab Emirates, Ukraine, and Yemen), Asia (China, Macau, Mongolia, Russia, Singapore, South Korea, and Taiwan), and South and Southeast Asia and Pacific (Cambodia, Guam, India, Indonesia, Nepal, Papua New Guinea, the Philippines, and Thailand).

The variable "positive external environment" was a continuous variable with a score from 3-13 ranging from the most negative to the most positive external environment. This variable was created by merging the responses to three items: the attitude of the local health office toward one's presence as a foreigner in the country, changes in ease of getting permission to initiate effective long-term medical work for expatriate medical workers, and degree of improvement in the quality of the local healthcare system compared to 5 or more years previously. The variable "changing medical need" was a continuous variable with a score from 2-10 ranging from the lowest to highest need for external medical assistance. This variable was created by merging the responses to two items: perception of need in the country for cross-cultural medical workers in their traditional roles and degree of improvement in the quality of the local healthcare system compared to 5 or more years previously.

Operationalization of the variables was carried out through an iterative process. A table was created containing each construct of interest, with each construct being assigned to one of the five expert panel members. The expert created 3-5 survey questions that could provide essential information regarding that construct. To select the survey questions that would best provide what was needed for that construct, the group dis- cussed all constructs. This group discussion went through five cycles of discussion and modification in order to ensure the validity of the questions and to eliminate nonessential or redundant questions. Content validity was established by a Delphi process among the members of the research team. Neither a content validity ratio nor a construct validity score was computed.

Face validity was established by pilottesting the survey in paper form on 10 people who met the inclusion criteria. The validity of the one-question screen for depression and anxiety was established as described above. Internal consistency of the instrument items was measured using the Chronbach's alpha and the Guttman split-half tests. The Chronbach's alpha test for anxiety and depression items was 0.597 . This level was considered acceptable for a selfadministered survey of this nature. A Guttman split-half coefficient of 0.639 was determined for the role satisfaction items. The survey was made available in on-line and paper format. The online version was made available through Survey Monkey. For security, an SSL survey link was used to encrypt response content in the event case responses were intercepted in transmission.

\section{Sample}

The population of interest in this study was English-speaking career missionaries working in healthcare. Inclusion criteria included: being an expatriate cross-cultural healthcare worker with qualifications in their home country, having served more than two years in their host country, officially associated with a Christian sending organization, and able to read and understand English well. The survey was open for 13 months, from February 2010 to February 2011. The paper version was distributed to attendees of the 2010 Continuing Medical and Dental Education Conference of the Christian Medical and Dental Association held in Limuru, Kenya and the 2011 conference held in Chiang Mai, Thailand, with 263 responses for a response rate of 54\%. Online versions of the survey were sent out to healthcare missionaries by a designated person from each of eight different mission organiza- 
tions willing to participate (CrossLink Global, Project MedSend, Christian Medical and Dental Association, Christian Connections in International Health, HCJB, the International Mission Board, ReachGlobal, and SIM), with 130 responses. It was not possible to calculate response rate for the on-line version because it was unknown how many individuals received the invitation to respond. A total of 419 surveys were completed. Twenty-six surveys were discarded because respondents did not complete the mandatory $60 \%$ of the questions or did not meet inclusion criteria, resulting in 393 valid responses. The protocol was approved by the Institutional Review Board of the Center for the Advancement of Healthcare Education and Delivery (CAHEAD), Colorado Springs, CO on November 24, 2009. C-AHEAD (www.c-ahead.org) is registered with the Department of Health and Human Services.

\section{Analyses}

Statistical tests all used significance level of .05. ANOVA and chi-square tests were performed on continuous variables to detect difference of means. IBM SPSS version 19 was used in data analysis. The PRISM Survey data base is available from the authors to others who might be interested in exploring other research questions.

\section{Results}

\section{Demographics}

Survey respondents came from 18 different English-speaking countries, with $76.5 \%$ from the United States. Mean age of respondents was 48 years (range: $24-85$ years), with 49.9 and $50.1 \%$ of respondents reporting to be male and female, respectively. Respondents reported an average of 11 years of field experience, with $41.2 \%$ reporting that they intended to serve in cross-cultural healthcare missions until retirement. Of those who responded, $67.7 \%$ were physicians, $17 \%$ were nurses, and $15.3 \%$ served in other healthrelated areas (Table 1).

\section{Work Situation by Region of the World}

Nurses made up $34.2 \%$ of the respondents from South America. A majority of the people from Asia and the Pacific were in family medicine. Africa and the Middle East had a greater proportion of surgeons than other regions (Table 1). The 67 countries of service were relatively evenly dispersed across the six main regions of the world (Fig 1), except that $38.9 \%$ of respondents were working in Africa, which reflects the approximate proportion of Christian healthcare workers who work in Africa.

Table 1. Healthcare missionaries primary area of training

\begin{tabular}{lcccccc}
\hline Area of training & \multicolumn{2}{l}{ Region of service } & & & Total \\
\cline { 2 - 7 } & $\begin{array}{c}\text { South } \\
\text { America }\end{array}$ & Africa & Middle & Asia & $\begin{array}{c}\text { South and } \\
\text { SE Asia } \\
\text { and Pacific }\end{array}$ \\
\hline Family/General Medicine & $23.7 \%$ & $30.1 \%$ & $41.9 \%$ & $44.4 \%$ & $52.2 \%$ & $37.9 \%$ \\
Nursing & $34.2 \%$ & $20.9 \%$ & $7.0 \%$ & $8.6 \%$ & $14.9 \%$ & $17.0 \%$ \\
Surgery or Surgical sub-specialties & $2.6 \%$ & $20.9 \%$ & $18.6 \%$ & $2.5 \%$ & $3.0 \%$ & $11.7 \%$ \\
Pediatrics & $10.5 \%$ & $7.2 \%$ & $9.3 \%$ & $4.9 \%$ & $17.9 \%$ & $9.4 \%$ \\
Internal Medicine or other medical & $5.3 \%$ & $6.5 \%$ & $4.7 \%$ & $8.6 \%$ & $1.5 \%$ & $5.6 \%$ \\
sub-specialties & & & & & & \\
Public health & $2.6 \%$ & $1.3 \%$ & $4.7 \%$ & $4.9 \%$ & $6.0 \%$ & $3.3 \%$ \\
Dentistry & $5.3 \%$ & $.7 \%$ & & $7.4 \%$ & $1.5 \%$ & $2.5 \%$ \\
Therapy, Rehab & $2.6 \%$ & $1.3 \%$ & $4.7 \%$ & $3.7 \%$ & $1.5 \%$ & $2.3 \%$ \\
OB, Gyn, Midwifery & & $3.3 \%$ & $4.7 \%$ & $1.2 \%$ & & $2.0 \%$ \\
Infectious Diseases & $2.6 \%$ & $.7 \%$ & $4.7 \%$ & $1.2 \%$ & & $1.5 \%$ \\
Psych, Soc, Counseling & & $2.0 \%$ & & $2.5 \%$ & & $1.3 \%$ \\
Optometry, Opthalm & $2.6 \%$ & $.7 \%$ & & & & $.5 \%$ \\
Pharmacy & & & & & $1.5 \%$ & $.3 \%$ \\
Other: & $7.9 \%$ & $4.6 \%$ & & $9.9 \%$ & & $4.6 \%$ \\
n & 38 & 153 & 43 & 81 & 67 & 393 \\
\% & $100.0 \%$ & $100.0 \%$ & $100.0 \%$ & $100.0 \%$ & $100.0 \%$ & $100.0 \%$ \\
\hline
\end{tabular}

Note. Chi-square $=120.48, \mathrm{p}<0.000$ 
$77.5 \%$ of the medical missionaries were working in a clinical setting (Table 2). Healthcare missionaries in South America, Afri$\mathrm{ca}$, and the Middle East primarily worked in a private hospital or clinic, including mission hospitals. Missionaries in Asia worked in a government clinic or out of their home or in an office space more than in other regions of the world.

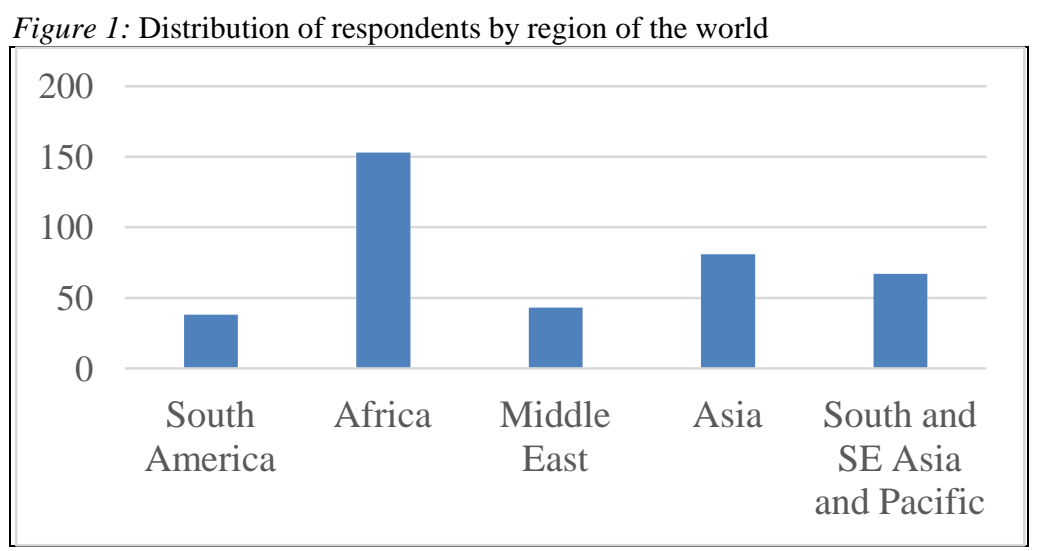

Table 2. Primary work setting

\begin{tabular}{lcccccc}
\hline Work setting & \multicolumn{2}{c}{ Region of service } & & & Total \\
\cline { 2 - 6 } & $\begin{array}{c}\text { South } \\
\text { America }\end{array}$ & Africa & Middle East & Asia & $\begin{array}{c}\text { South and SE } \\
\text { Asia and Pacif- } \\
\text { ic }\end{array}$ \\
\hline $\begin{array}{l}\text { Private hospital/clinic, in- } \\
\text { cluding mission hospitals }\end{array}$ & $63.2 \%$ & $60.1 \%$ & $60.4 \%$ & $32.1 \%$ & $45.5 \%$ & $65.0 \%$ \\
$\begin{array}{l}\text { Government hospital/clinic } \\
\text { Office of one's own organi- }\end{array}$ & $5.3 \%$ & $10.5 \%$ & $9.3 \%$ & $24.7 \%$ & $6.1 \%$ & $12.5 \%$ \\
zation or community partner & $10.5 \%$ & $15.1 \%$ & $4.6 \%$ & $17.3 \%$ & $24.3 \%$ & $15.3 \%$ \\
At home & $2.6 \%$ & $4.6 \%$ & $4.7 \%$ & $14.8 \%$ & $7.6 \%$ & $6.9 \%$ \\
In the community & $18.4 \%$ & $3.9 \%$ & $9.3 \%$ & $4.9 \%$ & $3.0 \%$ & $6.1 \%$ \\
Medical university & & $5.2 \%$ & $7.0 \%$ & $4.9 \%$ & $10.6 \%$ & $5.9 \%$ \\
Other: & 38 & $.7 \%$ & $4.7 \%$ & $1.2 \%$ & $3.0 \%$ & $1.8 \%$ \\
Total (n) & 153 & 43 & 81 & 66 & 392 \\
$\%$ & $100.0 \%$ & $100.0 \%$ & $100.0 \%$ & $100.0 \%$ & $100.0 \%$ & $100.0 \%$ \\
\hline
\end{tabular}

Note: Chi-square $=94.67, \mathrm{p}<0.000$

Table 3. Language used at work

\begin{tabular}{lcccccc}
\hline Language & \multicolumn{2}{l}{ Region of service } & & & Total \\
\cline { 2 - 7 } & $\begin{array}{c}\text { South } \\
\text { America }\end{array}$ & Africa & $\begin{array}{c}\text { Middle } \\
\text { East }\end{array}$ & Asia & $\begin{array}{c}\text { South and SE } \\
\text { Asia and } \\
\text { Pacific }\end{array}$ & \\
\hline $\begin{array}{l}\text { A local language other than English } \\
\text { (national language, trade language) }\end{array}$ & $78.9 \%$ & $32.9 \%$ & $51.2 \%$ & $46.9 \%$ & $34.3 \%$ & $41.8 \%$ \\
English & $7.9 \%$ & $31.6 \%$ & $14.0 \%$ & $8.6 \%$ & $22.4 \%$ & $21.4 \%$ \\
A mix of English and local language & $13.2 \%$ & $35.5 \%$ & $34.9 \%$ & $44.4 \%$ & $43.3 \%$ & $36.8 \%$ \\
Total n & 38 & 152 & 43 & 81 & 67 & 392 \\
$\%$ & $100.0 \%$ & $100.0 \%$ & $100.0 \%$ & $100.0 \%$ & $100.0 \%$ & $100.0 \%$ \\
\hline Note: Chi-square=60.95, $<<0.000$ & & & & & &
\end{tabular}

Missionaries that worked in South America reported using the local language the most in their work (Table 3 ). The workers with the lowest rate of using a local language were found in Africa. They relied on English or a mix of Eng- lish and a local language more than other regions. The Middle East and Asian regions required good facility in the local language as it is required for most of the work. 
Table 4: Main purpose of primary work setting

\begin{tabular}{|c|c|c|c|c|c|c|}
\hline \multirow[t]{2}{*}{ Main purpose of work setting } & \multicolumn{5}{|c|}{ Region of service } & \multirow[t]{2}{*}{ Total } \\
\hline & $\begin{array}{l}\text { South } \\
\text { America }\end{array}$ & Africa & $\begin{array}{l}\text { Middle } \\
\text { East }\end{array}$ & Asia & $\begin{array}{l}\text { South and SE Asia and } \\
\text { Pacific }\end{array}$ & \\
\hline $\begin{array}{l}\text { Purpose is like-minded to my } \\
\text { Christian faith }\end{array}$ & $94.6 \%$ & $80.3 \%$ & $65.1 \%$ & $45.7 \%$ & $70.1 \%$ & $71.1 \%$ \\
\hline $\begin{array}{l}\text { Secular but tolerant of expressions } \\
\text { of my faith in the workplace }\end{array}$ & $5.4 \%$ & $16.4 \%$ & $16.3 \%$ & $28.4 \%$ & $17.9 \%$ & $18.2 \%$ \\
\hline $\begin{array}{l}\text { Secular and not supportive of } \\
\text { expressions of my faith in the } \\
\text { workplace }\end{array}$ & & $3.3 \%$ & $18.6 \%$ & $25.9 \%$ & $11.9 \%$ & $10.7 \%$ \\
\hline Total & 37 & 152 & 43 & 81 & 67 & 391 \\
\hline$\%$ & $100.0 \%$ & $100.0 \%$ & $100.0 \%$ & $100.0 \%$ & $100.0 \%$ & $100.0 \%$ \\
\hline
\end{tabular}

Most respondents reported working in explicitly Christian settings, the exception being Asia, where the proportion was only $45.7 \%$ (Table 4). South America and Africa were both primarily Christian healthcare work, with some sec- ular work settings. The Middle East and Asia had Christian healthcare work, but also some secular work settings, many which are not supportive of the Christian faith, particularly in Asia.

Table 5. Quality of local health care system compared to five or more years previously

\begin{tabular}{lc|c|c|ccc}
\hline $\begin{array}{l}\text { Quality of health care delivery by the local } \\
\text { healthcare system }\end{array}$ & $\begin{array}{l}\text { Region of service } \\
\text { America }\end{array}$ & Africa & $\begin{array}{c}\text { Middle } \\
\text { East }\end{array}$ & Asia & $\begin{array}{c}\text { South and SE Asia and Pa- } \\
\text { cific }\end{array}$ \\
\hline Greatly improved & $12.1 \%$ & $4.3 \%$ & & $14.1 \%$ & $11.5 \%$ & $7.8 \%$ \\
Somewhat better & $39.4 \%$ & $46.4 \%$ & $47.5 \%$ & $69.2 \%$ & $47.5 \%$ & $51.1 \%$ \\
About the same & $33.3 \%$ & $31.2 \%$ & $37.5 \%$ & $14.1 \%$ & $26.2 \%$ & $27.7 \%$ \\
Somewhat worse & $9.1 \%$ & $13.0 \%$ & $12.5 \%$ & $1.3 \%$ & $6.6 \%$ & $8.9 \%$ \\
Greatly deteriorated & $6.1 \%$ & $5.1 \%$ & $2.5 \%$ & $1.3 \%$ & $8.2 \%$ & $4.5 \%$ \\
Total & 33 & 138 & 40 & 78 & 61 & 358 \\
$\%$ & $100.0 \%$ & $100.0 \%$ & $100.0 \%$ & $100.0 \%$ & $100.0 \%$ & $100.0 \%$ \\
\hline
\end{tabular}

Note: Chi-square $=39.76, \mathrm{p}=0.005$

Most regions of the world reported the local healthcare system significantly improved in the last five years, especially in Asia and South and SE Asia and Pacific and much less so in the Middle East (Table 5). $64.8 \%$ of respondents reported the local government to be very favorable or favorable to their presence there (Table 6) and only $1.3 \%$ considered the local government to be unfavorable. African workers report their local health office to be favorable toward them at a higher rate than in other regions. This favorable working relationship is extremely important to the ability of healthcare missionaries to have a positive impact and requires constant attention from leaders in medical missions.

Table 6. Attitude of local health officials toward your presence there

\begin{tabular}{lcccccc}
\hline \multicolumn{3}{c}{ Region of service } & & & Total \\
\hline $\begin{array}{l}\text { Attitude of your local health officials } \\
\text { toward your presence as a foreigner }\end{array}$ & $\begin{array}{c}\text { South } \\
\text { America }\end{array}$ & Africa & $\begin{array}{c}\text { Middle } \\
\text { East }\end{array}$ & Asia & $\begin{array}{c}\text { South and SE Asia } \\
\text { and Pacific }\end{array}$ \\
\hline Highly favorable & $13.2 \%$ & $23.5 \%$ & $19.0 \%$ & $11.1 \%$ & $19.4 \%$ & $18.9 \%$ \\
Favorable & $34.2 \%$ & $55.0 \%$ & $31.0 \%$ & $46.9 \%$ & $41.8 \%$ & $45.9 \%$ \\
Somewhat favorable & $34.2 \%$ & $13.4 \%$ & $33.3 \%$ & $23.5 \%$ & $19.4 \%$ & $20.5 \%$ \\
Unfavorable & & $.7 \%$ & & $2.5 \%$ & $1.5 \%$ & $1.3 \%$ \\
Not aware of your work & $18.4 \%$ & $7.4 \%$ & $16.7 \%$ & $16.0 \%$ & $17.9 \%$ & $13.5 \%$ \\
Total & 38 & 149 & 42 & 81 & 67 & 386 \\
$\%$ & $100.0 \%$ & $100.0 \%$ & $100.0 \%$ & $100.0 \%$ & $100.0 \%$ & $100.0 \%$ \\
\hline Note: Chi-square $=41.19, \mathrm{p}=0.004$ & & & & & &
\end{tabular}

Nov 2015. Christian Journal for Global Health 2(2): 23-38. 
The Middle East and South America had the largest portion of local health officials who were not highly favorable to their presence there. South America, Asia, South and SE Asia, and the Pacific reported the highest rate of their local government not being aware enough of their work to have an opinion that they would express (16-18.4\%). They were working out of public view more than others.

Table 7. Difficulty for expatriate healthcare workers to obtain permission to initiate long-term medical work

\begin{tabular}{lcccccc}
\hline \multicolumn{3}{c}{ Region of service } & \multicolumn{2}{c}{ Total } \\
\hline $\begin{array}{l}\text { Difficulty to obtain per- } \\
\text { mission }\end{array}$ & South America & Africa & Middle East & Asia & $\begin{array}{c}\text { South and SE Asia } \\
\text { and Pacific }\end{array}$ \\
\hline Getting harder & $13.2 \%$ & $22.4 \%$ & $51.2 \%$ & $46.9 \%$ & $35.8 \%$ & $32.3 \%$ \\
About the same & $55.3 \%$ & $58.6 \%$ & $34.9 \%$ & $29.6 \%$ & $47.8 \%$ & $47.2 \%$ \\
Easier & $7.9 \%$ & $5.9 \%$ & & $16.0 \%$ & $3.0 \%$ & $7.2 \%$ \\
I do not know & $23.7 \%$ & $13.2 \%$ & $14.0 \%$ & $7.4 \%$ & $13.4 \%$ & $13.3 \%$ \\
Total & 38 & 152 & 43 & 81 & 67 & 390 \\
$\%$ & $100.0 \%$ & $100.0 \%$ & $100.0 \%$ & $100.0 \%$ & $100.0 \%$ & $100.0 \%$ \\
\hline Note: Chi-square $=50.92, \mathrm{p}<0.000$ & & & & &
\end{tabular}

Getting permission to initiate effective long-term medical work for expatriate medical workers is getting more difficult (Table 7). As is shown below, health care delivery by the local system is improving in most regions of the world. Also, poor cooperation with the local system is considered to be the biggest external challenge workers face in their medical work in Asia and a significant challenge in other regions of the world. It isn't clear if this challenge to cooperation is due to reluctance on the part of locals or expatriate workers. But it could threaten the sustainability of medical missions in those contexts.

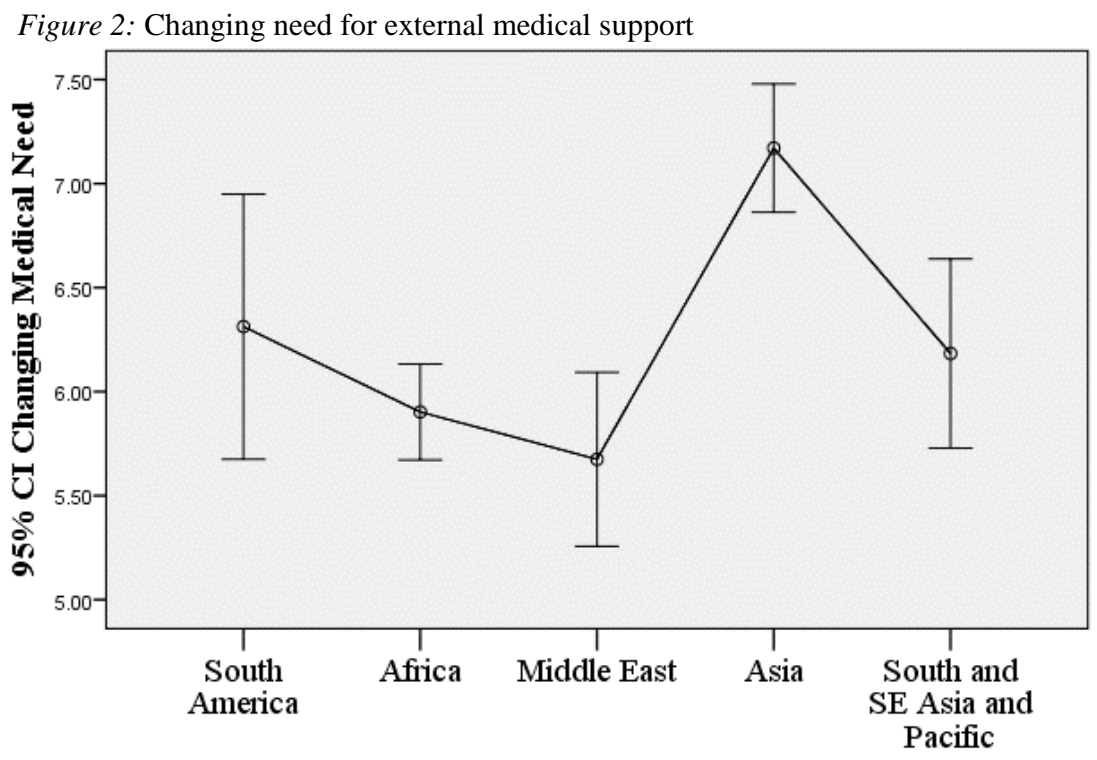

Region of service.

Note: Higher values represent less need 


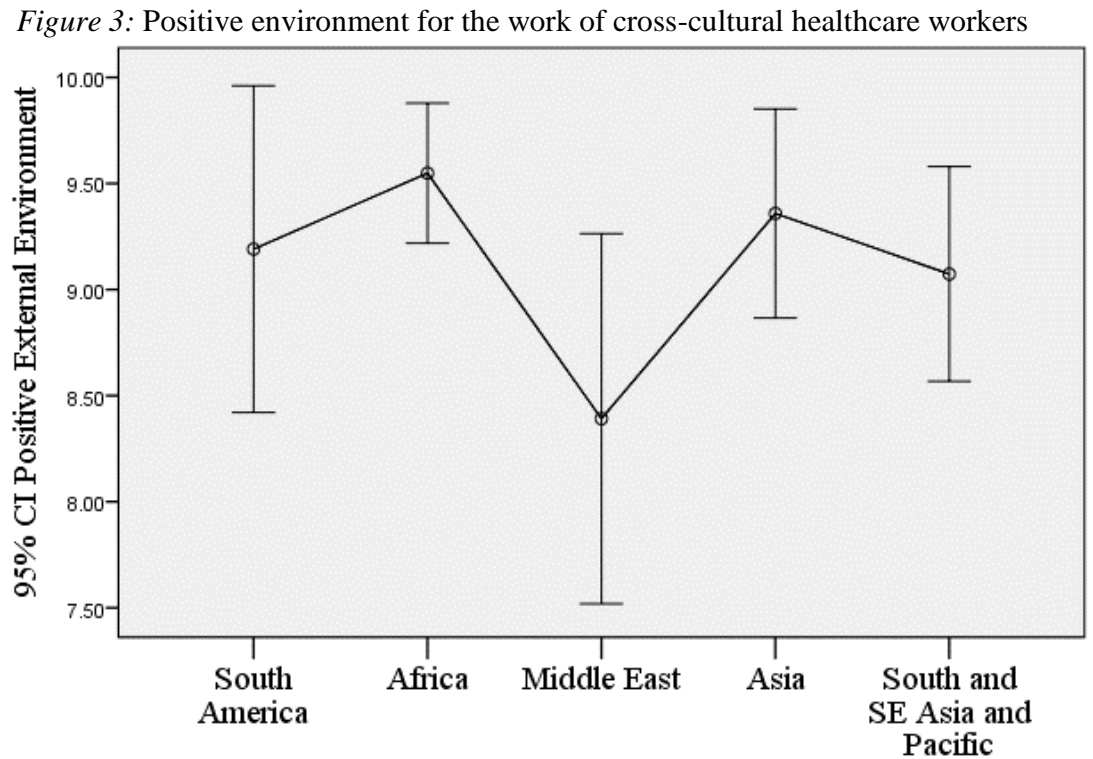

Region of service.

Note: Higher values represent more positive environment

The Middle East and African regions have the greatest need of external medical support, as defined by a worsening medical system and an ongoing perceived need of cross-cultural medical workers (Figure 2) (ANOVA F=10.97, p<.000). On the other hand, Asia has the least medical need as defined by an improving medical system and a decreasing perceived need of cross-cultural medial workers.

A less positive working environment was indicated by an unfavorable attitude of local offi- cials toward one's presence in their country, increasing difficulty in getting permission to work there long-term, and a worsening local healthcare system. The Middle East had the least positive working environment (Fig 3), but this difference was not statistically significant (ANOVA $F=2.35$, $\mathrm{p}<.056$ ). A less positive working environment was found associated with lower role satisfaction $(\mathrm{F}=2.81, \mathrm{p}=.026)$ and lower satisfaction with the balance of medical and non-medical aspects of their work $(\mathrm{F}=2.44, \mathrm{P}=.048)$.

Table 8. Attitude of your local health office and work satisfaction

\begin{tabular}{|c|c|c|c|}
\hline $\begin{array}{l}\text { Attitude of local health } \\
\text { officials toward your } \\
\text { presence there. }\end{array}$ & & $\begin{array}{l}\text { "I am satisfied with the } \\
\text { balance of medical and } \\
\text { non-medical aspects of } \\
\text { my work." }\end{array}$ & $\begin{array}{l}\text { "I am satisfied with my } \\
\text { current role as a cross- } \\
\text { cultural medical worker." }\end{array}$ \\
\hline Highly favorable & $\begin{array}{l}\text { Mean } \pm \text { SD } \\
\mathrm{N}\end{array}$ & $\begin{array}{c}2.11 \pm 1.205 \\
72\end{array}$ & $\begin{array}{c}1.93 \pm 1.079 \\
72\end{array}$ \\
\hline Favorable & $\begin{array}{l}\text { Mean } \pm \text { SD } \\
\mathrm{N}\end{array}$ & $\begin{array}{c}2.29 \pm 0.929 \\
172\end{array}$ & $\begin{array}{c}2.31 \pm 0.981 \\
170\end{array}$ \\
\hline Somewhat favorable & $\begin{array}{l}\text { Mean } \pm \text { SD } \\
\mathrm{N}\end{array}$ & $\begin{array}{c}2.35 \pm 1.057 \\
80\end{array}$ & $2.34 \pm 1.021$ \\
\hline Unfavorable & $\begin{array}{l}\text { Mean } \pm \text { SD } \\
\mathrm{N}\end{array}$ & $\begin{array}{c}3.00 \pm 1.000 \\
5\end{array}$ & $\begin{array}{c}1.80 \pm 0.837 \\
5\end{array}$ \\
\hline ANOVA F-value (p) & & $1.59(0.190)$ & $3.07(0.028)$ \\
\hline
\end{tabular}

Note: The values are read in reverse so a higher score reflects less satisfaction.

The more favorable the attitude of the local government toward their work, the more satisfied surveyed medical missionaries were with the balance of medical and non-medical aspects of their work $(\mathrm{F}=1.59, \mathrm{p}=0.190)$ and their role as a crosscultural medical worker $(\mathrm{F}=3.07, \mathrm{p}=0.028)$ (Table $8)$. 
Table 9. Mean anxiety and depression scores (0-5) and between group difference of means.

\begin{tabular}{lcc}
\hline Region of service & Anxiety & Depression \\
\hline South America & 3.69 & 2.78 \\
Africa & 3.08 & 2.47 \\
Middle East & 3.17 & 2.52 \\
Asia & 2.92 & 2.44 \\
South, SE Asia and Pacific & 2.72 & 2.37 \\
Total & 3.05 & 2.48 \\
ANOVA (p-value) & $2.539(.040)$ & $.405(.805)$ \\
\hline
\end{tabular}

Workers in South America and the Middle East reported the highest levels of anxiety, and the differences between regions were statistically significant (Table 9). In total, more than half of all respondents reported having experienced a bout of anxiety of level 4 or 5 .

The prevalence of anxiety was higher than depression in all regions, with $30 \%$ of all respondents reporting having experienced a bout of depression of level 4 or 5 , with a mean score of 2.48 out of 5 (Table 9). This cohort of respondents had been in missions an average of 10.8 years. It is frequently the case that those with organic depression, less influenced by situation, will have left the field by this time, as is supported by the small but significant negative correlation between depression score and years of service $(\mathrm{r}=-0.13, \mathrm{p}=0.015)$. There was a trend toward individuals residing in countries with lower perceived need of medical missionaries and a less positive work environment, having higher rates of depression and anxiety, but this difference was not statistically significant.

Table 10. Summary of characteristics of the healthcare mission situation in each major region of the world.

\begin{tabular}{|c|c|c|}
\hline Region & Characteristics of the political and healthcare system & Characteristics of healthcare missionaries working there \\
\hline $\begin{array}{l}\text { South } \\
\text { America }\end{array}$ & $\begin{array}{l}\text { Improving healthcare system } \\
\text { Local health officials favorable, but significant } \\
\text { lack of support also } \\
\text {. No change in difficulty of obtaining permission to } \\
\text { work there }\end{array}$ & $\begin{array}{l}\text { Nursing and family medicine. } \\
\text { Working in private hospital/clinic (including mission } \\
\text { hospital) } \\
\text {. } \quad \text { Almost exclusively Christian healthcare work } \\
\text { - Use the local language } \\
\text {. } \quad \text { Highest level of anxiety experienced }\end{array}$ \\
\hline Africa & $\begin{array}{l}\text { Improving healthcare system } \\
\text { - Local health officials most favorable toward ex- } \\
\text { patriate workers } \\
\text {. No change in difficulty of obtaining permission to } \\
\text { work there } \\
\text { - Need of expatriate workers remains } \\
\text {. The most positive working environment }\end{array}$ & $\begin{array}{l}\text { Family medicine, surgery and nursing } \\
\text { Working in private hospital/clinic (including mission } \\
\text { hospital) } \\
\text {. } \quad \text { Primarily Christian healthcare work, but also some } \\
\text { secular work settings } \\
\text { - Use mainly English more than other regions, but also } \\
\text { use a mix of English and local language } \\
\text {. Significant level of anxiety experienced }\end{array}$ \\
\hline $\begin{array}{l}\text { Middle } \\
\text { East }\end{array}$ & $\begin{array}{l}\text { The least improved healthcare system } \\
\text { - Local health officials favorable, but significant } \\
\text { lack of support also } \\
\text { - Getting harder to obtain permission to work there } \\
\text {. Need of expatriate workers greater than other } \\
\text { regions } \\
\text {. The least positive working environment }\end{array}$ & $\begin{array}{l}\text { Family medicine and surgery } \\
\text { Working primarily in private hospital/clinic and mis- } \\
\text { sion hospital) } \\
\text {. Much Christian healthcare work, but also some secular } \\
\text { work settings, many which are not supportive of the } \\
\text { Christian faith } \\
\text { Use the local language or a mix of English and the } \\
\text { local language } \\
\text { High level of anxiety, and highest level of depression, } \\
\text { experienced }\end{array}$ \\
\hline
\end{tabular}

Nov 2015. Christian Journal for Global Health 2(2): 23-38. 
Asia

- Local health officials favorable, but significant lack of support also

Some reports of getting harder to obtain permission to work there, but the highest portion reporting to be getting easier

Need of expatriate workers less than other regions

South - Improving healthcare system

and SE . Local health officials favorable, but significant

Asia and

Pacific lack of support also

Some reports of getting harder to obtain permission to work there, but mostly no change

\author{
Working in government hospital/clinic, or at home \\ more than other regions \\ - Least amount of Christian healthcare work, with many \\ secular work settings, and many that are not supportive \\ of the Christian faith \\ - Use the local language or a mix of English and the \\ local language \\ Moderate level of anxiety and depression experienced \\ Family medicine and pediatrics \\ Working in private hospital/clinic, or own office or \\ office of a community partner \\ Much Christian healthcare work, with many secular \\ work settings, some not supportive of the Christian \\ faith \\ - Use a mix of English and the local language \\ - Lowest level of anxiety and depression experienced
}

Table 10 summarizes the findings of this study for each region of the world. It is meant as a guide to organizations and individuals to assist in choosing a location for healthcare missions and knowing how to best support healthcare workers in those regions. There are differences in the range of improvement within countries from the same region, for example, Gaza to the United Arab Emirates or Afghanistan to Thailand, but the summary in this table serves as a starting point for evaluating the characteristics of the political and healthcare institutions in the region.

\section{Discussion}

\section{Work Situation by Region of the World South America}

Based on this research, missionaries in South America work almost exclusively in the local language and in Christian ministries. Nearly a fifth of them characterize their workplace as in the community. The level of engagement with the local healthcare system is relatively low compared to other regions studied. Local health personnel are seen as having a favorable or highly favorable attitude towards the expatriate work less than half the time, and they are very often unaware of the missionary's contribution. These individuals scored the highest measures of both anxiety and depression of any of the groups surveyed. One third of those responding from this region are nurses, which was higher than the other regions.

As in other regions, there is a perception among workers in South America that the health care system is improving. This perception that the local health care systems are doing relatively well along with the relative isolation of Christian work from the local systems likely contributes to a sense that the missionary's contribution is not needed, recognized, or appreciated. This sense may be partly responsible for high levels of distress experienced by these workers. Healthcare missionaries in South American countries have excellent language proficiency, so efforts to improve ties with local health systems and personnel could reduce the experience of isolation and give personnel opportunities to bring their gifts to a larger undertaking, which is already perceived as being successful.

\section{Africa}

There are more healthcare missionaries and a greater variety of health care work in Africa than in the other regions surveyed. Personnel in Africa have a strong sense of being needed and appreciated. Most of them work in English or in a combination of English and a local language. Africa is attractive to surgeons. Thirty-two surgeons responded from Africa, compared to a total of 13 for all the other regions. In addition, many family doctors in Africa perform surgery in their work settings. Several factors may contribute to this affinity. Of all the regions, African workers 
enjoy the most favorable opinion of their local counterparts. The African medical environment is needy. Obtaining permission for a surgeon to work is a complex process, so the combination of a needy situation and the high opinion of local coworkers helps to overcome the barriers to placing a surgeon in a productive work setting. The opportunity to contribute to the training of local surgeons is another attractive factor. Most health care missionaries in this region work in explicitly Christian health ministries. They perceive that local health care systems are slowly improving. In Africa, Christian ministries are likely to be incorporated into local and national healthcare systems, so missionaries are likely to feel that their personal and corporate input is partly responsible for gradually rising healthcare standards in their area.

\section{Middle East}

Historically, the Middle East has enjoyed a rich history of Christian medical ministry. The dedication of workers in this region is reflected by the fact that over half do their work in Arabic. The majority of personnel work in explicitly Christian settings in clinics or mission hospitals. Many have a working relationship with flourishing local churches, but nearly one in five works in settings hostile to the expression of their Christian faith. They work in a healthcare environment which is very needy and which, in some cases, is experiencing unprecedented pressures from refugees and immigrants. In some cases, health systems are deteriorating, yet the perceived level of external support for expatriate workers there is the lowest among the regions. In spite of the needs, it is getting more difficult for individuals to obtain permission to work in the nations where they serve.

Healthcare missionaries in the Middle East have relatively high levels of depression and anxiety. This is understandable in the light of ongoing conflict in the region and their difficulty in getting help. The majority of healthcare missionaries in the Middle East are family doctors, and the presence of missionary hospitals has made it possible for surgeons to make up the next largest group. There are relatively few nurses serving in this part of the world, though the presence of a number of Christian hospitals and clinics suggests that there might be room for more. Missiological strategies focusing on countries located in the 10/40 Window have increased the sense of urgency in missionaries to take assignments in the Middle East. "Push factors" from the sending churches are toward the Middle East, while "pull factors" of a positive work environment are the least of any region. This creates a tension, the greatest missiological need being out of sync with a hospitable work setting. High levels of anxiety and depression contribute to stress and attrition. The Middle East presents an opportunity for individuals who have a robust support system, good language skills, and a desire to work in a particularly needy region. Tolerance of physical danger, or perception of danger, to family and self is also important in many countries in this region.

\section{Asia}

Christian missionary healthcare personnel work in a wider variety of settings in Asia than elsewhere. Only about a third work in a private clinic or mission hospital setting, while nearly a fourth work in government facilities, and one in six work out of their homes. This is a result of several factors, including difficulty in obtaining medical licensure and securing a work position within a local healthcare institution, as well as the personal preference of some of the healthcare workers posted to these countries. Of the half who work in secular settings, about half of those experience an environment that is not supportive of expression of their faith, an even higher proportion than in the Middle East region. Personnel in Asia experience little external support for their work. Therefore, a strong team made up of expatriate and local healthcare professionals is critical.

Four out of five respondents felt that local health services in the region are improving. This was the highest of any region. Improving local health services and increasing difficulty obtaining permission for expatriate workers to work con- 
tributes to a low sense of need for expatriate medical assistance. In spite of these factors, missionaries in Asia score lower on measures of anxiety and depression than most other regions. Asia had the second largest number of respondents after Africa. As in other regions, the most prominent group is family doctors, at about $44 \%$. About a third of the balance is composed of nurses and internists. The breadth of training these generalists receive lends itself to the varied settings in which healthcare missionaries in Asia work. Missionaries who specifically desire to work outside of Christian institutions and who have the dedication necessary to learn the local language will do well to consider Asia. These individuals will benefit from a level of self-confidence that allows them to thrive and to live a unique personal Christian testimony as they contribute their gifts to a system that is functioning well without obvious need of expatriate support. It is extremely critical that a healthy and functional support system, made up of nationals and expatriates, be in place for workers is these contexts to thrive and be effective over the long term. Many Asian countries have re-emerging churches, so there are rich opportunities to contribute to the growth of a healthy church in those countries.

\section{South and South-East Asia and Pacific}

Healthcare missionaries in this region of the world experienced the lowest levels of depression and anxiety of the regions studied. Several factors may contribute to this relative contentment. In contrast to other regions, nearly half of those surveyed work in office or academic settings, sparing them the rigors of clinical work. Nearly a quarter of these personnel work in the office of their organization. Over $10 \%$ of personnel surveyed work in a university setting, which is the strongest academic engagement among the five regions. Workers are unlikely to be very dependent on the local language, with two-thirds working in English or partly in English. The area has the highest percentages of family doctors of any region. It also has the highest percentage of pediatricians and the highest percentage of public health specialists. Over two-thirds of respondents work in an expressly Christian setting, and nearly nine out of ten find themselves in a setting that is at least tolerant to the expression of their faith. This region had the highest percentage of respondents who reported that the local health system had "greatly deteriorated." The large number of respondents in this region from the countries of Cambodia and Nepal may explain this finding. Such response bias is one of the weaknesses of the present study. Overall, missionaries in this area are comparatively content, and they encounter fewer barriers to moving to this setting. They are very likely to work in a faith-friendly setting. They are less likely to be dependent on knowledge of the local language for their work and less likely to face the challenges, adjustments, and brutal hours associated with assuming a clinical role within the local healthcare system.

\section{General Observations}

The reasons for the preponderance of family doctors among missionary personnel are varied and were not addressed by this study. It is notable that surgical and medical specialties such as dermatology, cardiology, endocrinology, obstetrics, plastic and neurosurgery, and public health are valued in the regions studied. Surely individuals with these qualifications have an important role to play, but few people are exploiting those opportunities. It is possible that the sample used for this study is biased toward medical doctors, since two of the conferences at which surveys were done were heavily medical in nature. So these results affirm what can be done currently but are certainly not the limit of what can be done.

National health systems in all regions of the world, although not necessarily all countries, are improving. Ministries of health no longer look to expatriate medical missionaries to provide the bulk of medical services. Respondents in this survey observe that getting permission for medical missionaries to serve is getting more difficult in almost all countries. This trend affects the role of the medical missionary. Historically, medical 
missionaries were keen to serve the most underserved people. While there are always underserved populations, perhaps a new era characterized by focus on other areas of need has arrived. The opportunity to strategically engage the national health system in its development and have a broader impact is a present possibility. Following are several examples of such impact. Seven Christian denominations and non-governmental organizations in Australia have a 10-year Papua New Guinea Community Partnerships Program to invest long-term in building the country's healthcare infrastructure. ${ }^{15}$ North American family physicians associated with the In His Image Family Medicine Residency program have been instrumental in helping the Ministries of Health of several Asian countries establish Family Medicine as a discipline. ${ }^{16,17}$ Others have successfully modeled family practice medicine and evidence-based chronic disease management in China's own community-based clinics. ${ }^{18,19}$ In Africa many are engaged in improving undergraduate and graduate medical education in partnership with national and local universities and in concert with national ministries of health. ${ }^{20,21}$ In Africa and India, mission hospitals have served as centers of innovation for surgical procedures and training. ${ }^{22,23}$ In other settings, expatriate healthcare workers have been instrumental in conducting collaborative research in a way that increases the research capacity of national partners. ${ }^{24}$ All in all, medical missions work is facing increased regulation by the government health agencies in their countries of service. This should be a welcomed change, as it ensures the efforts are in line with national health priorities, and it might bring increased funding or legislation to help with sustainability and impact. Individuals and ministries engaged with local or national healthcare systems in projects to improve healthcare education, delivery, or quality may also be less likely to face barriers to gaining permission to work. But it also has the potential to squeeze out small or unique missions efforts or add bureaucracy that the medical mission cannot sustain.

\section{Mental Health}

Those who choose to make a long-term commitment to working in a country other than their "home country" are at risk for experiencing stress, including social isolation, cultural adjustment, and repatriation. ${ }^{7,8,10}$ In a review of the literature, Foyle and Watson reported a high incidence of affective and adjustment disorders among career missionaries. ${ }^{10,25}$ The PRISM Study found 60.1 and $65.8 \%$ of men and women to have experienced a moderate to serious bout of anxiety, and 45.0 and $55.5 \%$ of men and women to have experienced a moderate to serious bout of depression. ${ }^{26}$ As a baseline for comparison, the lifetime prevalence of depression among physicians in the U.S. is $12 \%$ for men age $45-54$ and $19.5 \%$ for women, although the method of measurement used was different from that used in the PRISM Study. ${ }^{27}$

Anxiety and depression are distinct but related psychological conditions, ${ }^{28}$ with comorbid anxiety present in $50 \%$ of persons with major depression. $^{29}$ Depression is a pervasive human disorder that affects all spheres of functioning. ${ }^{30,31}$ Depression has been shown to impact work performance and well-being. ${ }^{32}$ Research on missionary performance has shown anxiety and moodiness as key indicators of performance. ${ }^{33-36}$ More research is needed in the area of mental health of missionaries.

There are many factors contributing to dissatisfaction with the balance of work and ministry in the life of a missionary. External factors include long hours, frantic pace, grief, and emotional strain associated with clinical work in an under-resourced facility. Lack of time for strictly spiritual ministry may lead to disappointment, frustration, and even guilt. Internal factors may prevent a person from creating a satisfying balance. Regardless, the attitude of the local health system affects both work satisfaction and mental health.

A strong marriage and family are assets to flourishing on the mission field. Missionaries need resilience and patience as they cope with the

Nov 2015. Christian Journal for Global Health 2(2): 23-38. 
challenges of working in that setting. Good mental health and resources to cope with periods of stress and anxiety need to be in place ahead of time. The extent of depression experienced by respondents to this survey reflects a significant burden of disease. The small but significant negative correlation between depression score and years of service suggests that the depressive symptoms are not primarily due to endogenous factors such as primary depressive disorder. Other factors either produce depressive symptoms directly or stimulate depressive symptoms in persons with a depressive vulnerability. Anxiety, on the other hand, is more sensitive to the context in which one works. Pre-field security training to include risk assessment, contingency planning, and measures to mitigate risk are strongly recommended.

This study reveals a need for research that can inform strategic planning of healthcare missions and can help individuals make informed decisions about desirable settings for healthcare missions. Such research could shed light on strategies to overcome challenges and to take full advantage of opportunities present in a given setting. A more complete description of what types of healthcare mission work is occurring in countries or regions of the world are needed. Some measure of success is needed in order to evaluate which of the many healthcare mission approaches are effective, and what variables contribute to that effectiveness. The literature is virtually silent on the perceptions of officials or local healthcare workers in the host countries toward the value brought by expatriate workers and their organizations. Research methods that include those individuals is very much needed.

\section{Limitations}

The main threat to the validity of this study is selection bias. Those who chose to participate were not randomly chosen and may not represent the broader healthcare missions community. Additionally, the sample is made up of North American evangelical healthcare missionaries. Therefore, the study is missing significant contributions from Roman Catholics, individuals serving in ecumenical organizations, and individuals who are working in secular global health organizations. Furthermore, by limiting the study to English-speaking respondents, the input of healthcare missionaries from countries such as Brazil, Korea, and many others is absent.

The researchers designed the instrument used in this study and limited external validity analyses were performed. This is a limitation of the study. It is the intention of the authors to use this instrument with other samples of medical missionaries to more rigorously test its validity. Another limitation is the cross-sectional nature of the study, which does not allow the determination of a temporal relationship of anxiety/depression and other reported variables.

There is significant country variability within a given region, so although regions have been generalized, one would need to look carefully at each individual country to understand the circumstances and details present there. Additionally, the responses are the subjective opinion of the healthcare missionaries themselves, so the degree to which they accurately reflect the local situation is probably of varying validity.

\section{Conclusion}

The work of global healthcare missions continues to have a large impact on the health of people in need. The challenges facing today's health care professional working overseas are different than in the past. It is the intention of the authors to provide healthcare mission candidates and organizational leaders with an overview of the changing global context and current opportunities and challenges facing them. Despite changes, with creativity, flexibility, and some specialized pre-field training, there remain large arrays of opportunities. For example, healthcare missions afford many opportunities, ranging from holistic ministry to healthcare system redesign. The healthcare missionaries surveyed were working in primary care or in private or government clinics, in most settings, with more surgery being performed in Africa and the Middle East. The 
work of healthcare missionaries occurs within a political context. While open opposition or hostility toward these expatriate healthcare missionaries is rare, the degree to which they are welcomed or understood varies by region. Although the local healthcare systems are generally improving, the work of the healthcare missionaries is not associated significantly with the local healthcare system and has limited impact on it. This will need to change in order to increase the impact and strengthen the sustainability of this work.

\section{References}

1. Johnson T. Christianity in its global context, 19702020: society, religion, and mission. Southhampton, MA: Center for the Global Study of Christianity; 2013.

2. Jaffarian M. The statistical state of the North American Protestant missions movement. in The Mission Handbook, 20th edition. International Bulletin of Missionary Research 2008;32:35-8.

3. Panosian C, Coates TJ. The new medical "missionaries" - grooming the next generation of global health workers. New Engl J Med. 2006;354:1771-3. http://dx.doi.org/10.1056/NEJMp068035

4. Asgary R, Junck E. New trends of short-term humanitarian medical volunteerism: professional and ethical considerations. J Med Ethics. 2013;39:625-31. http://dx.doi.org/10.1136/medethics-2011-100488

5. Summit MM. Informal report from eight missions organizations attending the meeting. Atlanta, GA: Center for Medical Missions, Christian Medical and Dental Association; 2012.

6. Strand M, Wood A. That healthcare missionaries might flourish: global healthcare workers needs assessment report. Fargo, ND: MedSend; 2015.

7. Bikos L, Lewis Hall E. Psychological functioning of international missionaries: introducion to the special issue. Ment Health, Relig \& Cult. 2009;12:605-9. http://dx.doi.org/10.1080/13674670903312427

8. Eriksson C, Bjorck J, Larson L, et al. Social support, organisational support, and religious support in relation to burnout in expatriate humanitarian aid workers. Ment Health, Relig \& Cult. 2009;12:671-86. http://dx.doi.org/10.1080/13674670903029146
9. Grundmann C. The contribution of medical missions to medical education overseas. Mission Studies. 1992;9:79-99.

10. Foyle M, Watson J. Expatriate mental health. Actu Psychiatr Scand 1998;97:278-83.

11. Koteskey R. Psychology for missionaries. Wilmore, KY: GO International; 2011.

12. Hawley D. Research on missionary kids and families: a critical review. Dallas: Missions Resource Network; 2004.

https://www.mrnet.org/system/files/library/critical_rev iew on mks families.pdf

13. APA. American Psychiatric Association: Diagnostic and Statistical Manual of Mental Disorders. 5th ed. Arlington, VA: American Psychiatric Association; 2013.

http://dx.doi.org/10.1176/appi.books.9780890425596

14. Carey M, Jones KA, Yoong SL, et al. Comparison of a single self-assessment item with the PHQ-9 for detecting depression in general practice. Family Practice. 2014;31:483-9. http://dx.doi.org/ doi: $\underline{10.1093 / \text { fampra/cmu018 }}$

15. Clarke M. Innovative delivery mechanisms for increased aid budgets: lessons from a new Australian aid partnership. Working Paper number 2011/73. United Nations UniversityNovember 2011.

16. In His Image Program. [Internet]. [cited 2015 September 21]. Available from:

http://www.inhisimage.org/program.php\#!/.

17. About the Center for Global Health Education. 2015. [Internet]. [cited 2015 September 23]. Available from: http://www.utmb.edu/ccgh/education/china.asp

18. Medicine, Rehabilitation and Public Health. [Internet\}. [cited 2015September 21]. Available from: http://www.evergreenchina.net/home/index.php?optio $\underline{\mathrm{n}=\mathrm{com} \_ \text {content } \& v i e w=\text { article } \& \mathrm{id}=114 \& \text { Itemid }=150}$

19. Strand M, Zhao Y, Zhang T. Evaluation of the effectiveness of an intervention on 615 hypertensive patients. J Commun Med [Chinese]. 2012;10:82-3.

20. Kingsnorth A, Gyoh S. Is it possible to train surgeons for rural Africa? A report of a successful international program. World J Surg. 2012;36:1439-40.

21. Tarpley JL. Commentary: an academic track in global surgery. Surgery 2013;153:322-4. http://dx.doi.org/10.1016/j.surg.2012.08.048 
22. Chao T, Rosenberg J, Patel P, Riviello R, Weintraub R. Surgery at AIC Kijabe Hospital in rural Kenya. In Global surgery teaching cases: volume 1. Boston, MA: Harvard Medical School and Brigham and Women's Hospital; 2014 April. Available at: http://www.globalsurgery.info/wpcontent/uploads/2013/10/Global-Surgery-TeachingCases_rev2-2-copy.pdf

23. Gnanaraj J, Lau X, Khiangte H. High quality care at low cost: the diagnostic camp model of Burrows Memorial Christian Hospital. Indian J Surg. 2007;69:243-7. http://dx.doi.org/10.1007/s12262-0070034-0

24. Gnanaraj J. Working holidays for overseas doctors: host perspective in mission hospitals in rural India. Christ J for Glob Health. 2015;2:35-42. http://journal.cjgh.org/index.php/cjgh/article/view/53

25. Peppiatt R, Bypass P. A survey of the health of British missionaries. Br J Gen Pract. 1991;41:159-62.

26. Strand M, Goodman L, Chen A, Richardson J. Mental health of cross-cultural healthcare missionaries. J Psychol Theol. 2015; in print.

27. Center C, Davis M, Detre T, Ford DE, Hansbrough $\mathrm{W}$, Hendin $\mathrm{H}$, et al. Confronting depression and suicide among physicians: a consensus statement. JAMA 2003;289:3161-6.

http://dx.doi.org/10.1001/jama.289.23.3161

28. Clark LA, Watson D. Tripartite model of anxiety and depression: psychometric evidence and taxonomic implications. J Abnorm Psychol. 1991;100(3):316-36. http://dx.doi.org/10.1037/0021-843X.100.3.316
29. Fava M, Uelbacker L, Alpert J, Nierenberg A, Pava J, Rosenbaum J. Major depressive subtypes and treatment response. Biol Psychiat. 1997;42:568-76. http://dx.doi.org/10.1016/S0006-3223(96)00440-4

30. Richards D. Prevalence and clinical course of depression: a review. Clin Psychol Rev. 2011;31:111725. http://dx.doi.org/10.1016/j.cpr.2011.07.004

31. Lepine J, Briley M. The increasing burden of depression. Neuropsychiatr Dis Treat. 2011;7:3-7. http://dx.doi.org/10.2147/NDT.S19617

32. Lerner D, Henke R. What does research tell us about depression, job performance and work productivity? J Occup Environ Med. 2008;50:401-10. http://dx.doi.org/10.1097/JOM.0b013e31816bae50

33. Rosik C, Ordway A, Tafoya J. Assessing the effectiveness of intensive outpatient care for Christian missionaries and clergy. Ment Heal, Relig Cult. 2009; 12:687-700. http://dx.doi.org/10.1080/13674670903312427

34. Britt W. Pretraining variables in the prediction of missionary success overseas. J Psychol Theol. 1983;11:203-12.

35. Judge T, Thoreson C, Bono J, Patton G. The job satisfaction-job performance relationship: a qualitative and quantitative review. Psychol Bull. 2001;127:376407. http://dx.doi.org/10.1037/0033-2909.127.3.376

36. Cousineau A, Lewis Hall M, Rosik C, Hall T. Predictors of missionary job success: a review of the literature and research proposal. J Psychol Chr. 2010;29:354-63.

Peer Reviewed

Competing Interests: None declared.

Correspondence: Mark A Strand, PhD, North Dakota State University, 118L Sudro Hall, Fargo, ND, 58101. Fax: 701-231-7606. Mark.Strand@ndsu.edu

Cite this article as: Strand, MA, Paulson, E and Myrick, T. Characterizing the global context for cross-cultural healthcare work by regions of the world. Christian Journal for Global Health (Nov 2015), 2(2):23-38.

(C) Strand, MA, Paulson, E and Myrick T. This is an open-access article distributed under the terms of the Creative Commons Attribution License, which permits unrestricted use, distribution, and reproduction in any medium, provided the original author and source are properly cited. To view a copy of the license, visit http://creativecommons.org/licenses/by/3.0/

$$
\text { www.cjgh.org }
$$

Nov 2015. Christian Journal for Global Health 2(2): 23-38. 